JMKSP (Jurnal Manajemen, Kepemimpinan, dan Supervisi Pendidikan)

Volume 7 Issue 1 (2022) Page 154-162

ISSN 2614-8021 (Online) 2548-7094 (Print)

\title{
Perception of Students of Indonesian Language Study Program on Learning at E-Learning Sisfo Universitas PGRI Palembang
}

\author{
Masnunah $^{1}$, Wandiyo ${ }^{1}$, Riswan Aradea ${ }^{1}$ \\ ${ }^{1}$ Universitas PGRI Palembang \\ Corresponding Author E-mail: masnunah42@gmail.com
}

Received 4 August 2021; Revised 2 December 2021; Accepted 15 January 2022

\begin{abstract}
Learning during a pandemic or epidemic period, face-to-face learning has now become a lesson for the virtual world. From these problems online learning is one solution in carrying out the teaching and learning process, but online learning is not as easy as imagined, and there are many obstacles in learning, especially when providing material, there are several obstacles that make the learning process less effective and efficient. At PGRI University Palembang, learning through cyberspace is called SISFO E-Learning learning. The purpose of this study, based on the formulation of the problem above, is to find out student perceptions of online learning at SISFO E-Learning at PGRI Palembang University during the Covid-19 pandemic for the 2020-2021 academic year even semester. Based on the conclusions from the six indicators, namely in the form of affinity indicating the High category, thinking reflection showing the High category, interaction showing the High category, teacher support showing the High category, level support showing the High category and interpretation showing the High category of the six indicators, the average percentage is $77.33 \%$ in the High category.
\end{abstract}

Keyword: Perception, Students, E-Learning, SISFO

\section{Introduction}

Education is important in human design, besides work which often determines the welfare of a country. Education is carried out to improve students' 
abilities through learning activities. Therefore, students must be active, creative, and innovative in answering all the lessons taught. Inviting someone who is active, creative and creative in students is not an easy thing. The fact is that the teacher regards it as the same course and the student becomes the subject of the previous course. As a result, the teaching and learning process is disrupted and has an impact on student learning outcomes.

According to (Helmawati, 2019) learning is a higher order thinking skill (HOTS) or critical thinking that is recommended to be carried out in a quality education process. In addition, in the Industrial Revolution Era 4.0 as it is today, developing science and technology has an effect on changes that continue without stopping in all fields due to continuous changes, humans are required to be able to adapt through changes in mental attitudes, knowledge, and skills. According to (Haris, 2019) learning is a process activity and is a very fundamental element in organizing the type and level of education, this means that the success of achieving educational goals is highly dependent on the success of the learning process of students in schools and the surrounding environment. In that case it raises students' perceptions of online learning, perception is a process that involves messages about giving meaning received through students' perceptions of continuously making connections through their environment, this relationship is carried out through their senses, namely the senses of sight, hearing, touch, taste and smell. From the perceptions of these students, an evaluation will be held regarding the advantages and disadvantages of online learning by the relevant teachers, and it is hoped that with the students' perceptions of online learning, they can get information.

According to Lestari, N. D., Rachmawati, D. W., \& Yusmiono, B. A. (2021) this makes it easier for students who are still not able to master the lesson, which should make it easier for them to understand the lesson below circumstances. Then with this classical teaching system makes them reluctant or lazy to be able to understand more about the lesson, even though the lesson will be easy to understand if educators can implement a teaching system that attract students' attention to arouse their curiosity, and arouse their creativity that student.

With the opinions or responses of students in online learning through SISFO E-Learning, the researchers took steps for internal factors such as the activeness of students in responding or providing responses to the material presented by the subject teacher and also external factors that came from outside the individual. Such as network or signal disturbances, an environment that is less conducive so 
that it makes students less concentrated in learning. Internal factors are factors that include monitoring systems such as cognitive, affective and psychomotor. While external factors include the social environment. Until now, the perception of students towards online learning in economics is not known, therefore the perception given by students is very important to determine the final outcome of the online learning process, through the SISFO E-Learning which is owned by the University of PGRI Palembang.

Based on the information obtained from the Indonesian Language Education Study Program, PGRI University Palembang, basically online learning is carried out when there is a circular regarding the implementation of distance learning by using application media such as zoom, google classroom, WhatsApp and others, and the teaching and learning process is also carried out according to applicable procedures and conditions.

According to Ningsih, M. W., Lestari, N. D., \& Pramika, D. (2021). The choice of learning media affects the success of teaching carried out by educators in the teaching and learning process, Teachers must be careful and thorough in choose the teaching materials used during the learning process, if the teacher uses an interesting way learning media, students will be motivated to watch, understand and learn. Learning media is made according to the needs and characteristics of the material to be given so that can get the desired learning results. The purpose of this research, based on the formulation of the problem above, is to find out the perceptions of students of the Indonesian language study program towards online learning at SISFO E-Learning at PGRI Palembang University during the Covid-19 pandemic for the 2020-2021 academic year even semester.

The benefits of this research are: Being able to grow the enthusiasm and motivation of students of the Indonesian language education study program to be able to master and utilize digital technology in learning, in the era of the industrial revolution 4.0, especially in SISFO E-Learning. As well as increasing student creativity to be good at processing digital technology properly and correctly, so that the millennial generation is able to answer challenges and obstacles in the era of the industrial revolution 4.0.

Someone's opinion, to express something based on what they see, they hear in fact, they will put it in an opinion or in words and perceptions. According to (Listyana \& Hartono, 2015, p. 121) Perception is a process of self-interpretation 
to know and evaluate the extent to which we know other people. In this process the sensitivity in a person to the surrounding environment.

According to (Jayanti \& Arista, 2018) Perception is one of the important psychological aspects for humans in responding to the presence of various aspects and symptoms around them. A person's view of something that is influenced by knowledge, desires and experiences that react to the five senses. (Paradikma, 2019).

Based on the opinion above, perception is the interpretation of a person based on several aspects, which can describe the view based on the experience of events experienced in fact or actually. Online learning is based on distance learning that uses media or other devices as a tool to facilitate learning, so that everyone has the same learning opportunities.

According to (Ayuni, Marini, Fauziddin, \& Pahrul, 2021) Online learning is the implementation of online learning classes to reach a massive and broad target group, so that learning can be held anywhere and can be attended for free or prepaid. According to (Sadikin \& Hamidah, 2020) Online Learning is learning that uses the internet network with accessibility, connectivity, flexibility and the ability to bring up various types of learning interactions. Meanwhile, according to

Based on the opinion above, online learning is learning in a network that can reach all lines, but must have network devices such as the internet, online learning can use assistive media in applications both on laptops and mobile phones such as zoom, google classroom and so on. .

E-Learning is a means in the learning process that uses information technology, E-Learning learning media is very much needed, especially during the COVID-19 pandemic. According to (Hanum, 2013) E-learning is a form of information technology that is applied in the field of education. in the form of a virtual world. E-learning is a form of learning model that is facilitated and supported by the use of information and communication technology.

E-learning is an effort to transform the teaching and learning process in schools into digital form supported by information technology (internet) (Wulandari \& Nugoroho, 2015). According to (Sifuddin) E-learning is a form of internet use that can increase the role of students in the learning process.

Based on the above opinion, E-learning is an information technology system that is applied to the field of education, helping educators and students in the learning process, in using E-Learning using a tool, namely the internet which is 
the main network so that $\mathrm{n}$ devices can be used properly, then the internet must be good too.

\section{Methods}

The research design or research method is about what method is used (Sugiyono, 2016). The method used in this research is descriptive research method. According to Sugiyono (2016) descriptive research is research conducted to determine the value of independent variables, either one or more (free) variables without making comparisons or connecting with other variables. This research method intends to reveal a problem or phenomenon by using the SISFO E-Learning Learning media faced by students of the Accounting Education Study Program, FKIP University PGRI Palembang, with Documentation and Questionnaire data using Google From. This research is a process with various steps in finding solutions to problematic problems to help make the right decisions.

\section{Results and Discussion}

The research was carried out at PGRI University Palembang, Faculty of Teacher Training and Education (FKIP) Indonesian language study program, due to the limitations of the researchers only researching students who were teaching researchers, namely as many as 102 students as research subjects. Data collection techniques used are documentation and questionnaire techniques. Students are asked to fill out a closed questionnaire with 48 questions already in the SISFO ELearning. The research involved 3 students to assist researchers in preparing the research.

The results of students' perceptions of learning through SISFO E-learning at PGRI Palembang University, based on the indicators that have been set, can be seen in the table below;

Table 1. Students' Perceptions On Learning Through Sisfo E-Learning

\begin{tabular}{|l|l|c|c|c|c|c|}
\hline \multirow{2}{*}{ No } & \multirow{2}{*}{ Indicator } & \multicolumn{3}{|c|}{ F\% } & Average & \multirow{2}{*}{ Category } \\
\cline { 3 - 6 } & & BI 2.A & BI 6A & BI 6B & & \\
\hline $\mathbf{1}$ & Relationship & 75.91 & 85.70 & 78.17 & 79.93 & high \\
\hline $\mathbf{2}$ & Thinking Reflection & 71.71 & 76.55 & 76.00 & 74.75 & high \\
\hline $\mathbf{3}$ & Interaction & 71.45 & 76.73 & 73.84 & 74.01 & high \\
\hline $\mathbf{4}$ & Teacher Support & 70.92 & 85.52 & 77.17 & 77.87 & high \\
\hline $\mathbf{5}$ & Level Support & 72.11 & 82.07 & 73.83 & 76.00 & high \\
\hline $\mathbf{6}$ & Interpretation & 78.29 & 86.38 & 79.67 & 81.45 & high \\
\hline & Average \% & $\mathbf{7 3 . 4 0}$ & $\mathbf{8 2 . 1 6}$ & $\mathbf{7 6 . 4 5}$ & $\mathbf{7 7 . 3 3}$ & high \\
\hline & Frequency \% & $\mathbf{1 9 . 4 9}$ & $\mathbf{2 1 . 8 2}$ & $\mathbf{2 0 . 3 0}$ & $\mathbf{1 0 0}$ & \\
\hline
\end{tabular}


Based on the results of a questionnaire from 102 students of the Indonesian Language Education Study Program, FKIP Unversitas PGRI Palembang, the closed questionnaire consisted of 48 questions, with an average indicator of $77.33 \%$ in the Good category.

In this study, the things that will be discussed are related to statements by students of Indonesian Language Education Study Programs about Relationships, Thinking Reflections, Interaction, Teaching Support, Level Support and Interpretation.

The statement on the indicator of student affinity or relationship with learning is related to students preferring and finding that the focus of learning is on issues that interest students. Students prefer and find that what they learn is important for their professional practice. Students prefer and find that learning to develop professional practice. I prefer and find that what I learn relates well to professional practice. The student's response to the statement on the relationship indicator is high.

Reflection of thinking is internal, where in one's efforts to find and like things in the form of critical ideas that exist in their own potential. In this study, the indicator of student thinking reflection was given questions related to students preferring and finding that they think critically about how to learn. Students prefer and find that they think critically about their own ideas. Students prefer and find that thinking critically about the ideas of colleagues or other students. Students prefer and find that they think critically about ideas in reading. For the indicator of thinking reflection, the average respondent gives a statement in the High category.

Online learning actually causes the interaction of all these things because the problems that arise are in the form of a lack of student understanding of the learning process while using SISFO e-learning. This can be seen from the condition of students who are still classified as unstable learners, many have difficulty understanding learning so that the role of supervisors other than lecturers is needed in distance learning. However, for indicators of interactions carried out during learning using SISFO E-learning in the High category, this is based on questions. Students prefer and find that explaining their ideas to other students. Students prefer and find that asking other students to explain their ideas. Students liked it more and found that other students asked to explain my idea. Students liked it more and found that other students responded to my ideas. 
The role of the teacher is very meaningful as teacher support, based on the Javanese proverb where the teacher is someone who is uplifted and imitated, where his figure is idolized, becomes a role model for students. Support Lecturers as professional teachers with the task of not only educating, teaching, guiding but also being able to direct, train, assess and evaluate every learning process that has been passed with their students. When learning through E-learning sisfo, with questions. Students prefer and find that the teacher stimulates my mind. Students liked it more and found that the teacher encouraged me to participate. Students prefer and find that the teaching model is good in giving discourse. Students prefer and find that the teaching model criticizes personal reflection.

Support level, namely students are assisted by other students or their friends in learning, the point is to provide motivation for peer learning. Support at the same level can assist in guiding activities in the form of enrichment in solving learning problems. This level of support creates a sense of responsibility and student confidence in the learning process, especially in online learning using Sisfo's e-learning, this is proven by student statements about Level Support showing it is in the High category. Questions on the Support indicator level are students prefer and find that other students encourage their participation. Students liked it more and found that other students praised their contribution. Students liked and found that other students appreciated their contributions. Students liked and found that other students were empathetic with their struggles to learn.

Interpretation in research, researchers do Interpretation is able to minimize misunderstandings and misinterpretations. Interpretation can be part of the presentation or description of changes in information, to adjust to a certain set of symbols, interpretations made by researchers through oral, written, and gestures. Interpretation is done to express ideas that can be understood and understood. The state of understanding or understanding is not based on timing, but is natural. So in this study, it was found that interpretation is giving an impression, opinion, or theoretical view on something, explanatory text can be in the form of exposing the conclusions of the problems expressed by giving a brief opinion. Based on this, student interpretation of online learning with E-learning SISFO shows the categories Tall.

\section{Conclusion}

Based on the conclusions from the six indicators, namely in the form of affinity indicating the High category, thinking reflection showing the High 
category, interaction showing the High category, teacher support showing the High category, level support showing the High category and interpretation showing the High category of the six indicators, the average percentage is $77.33 \%$ in the High category.

\section{Acknowledgement}

We would like to thank the Universias PGRI Palembang, to LPPKM, to the Dean of FKIP and thanks are also conveyed to all parties who have contributed to this research. Further thanks are conveyed to all students for their contribution in helping with data collection. Thank you to the JMKSP team (Journal of Management, Leadership, and Education Supervision) for providing input in the peer review process.

\section{References}

Ayuni, D., Marini, T., Fauziddin, M., \& Pahrul, Y. (2021). Kesiapan Guru TK Menghadapi Pembelajaran Daring Masa Pandemi Covid-19 [Kindergarten Teachers' Readiness in Facing Online Learning During the Covid-19 Pandemic]. Jurnal Pendidikan Anak Usia Dini, 5 (1), 414 - 421.

Azwar, S. (2012). Penyusunan Skala Psikologi [Psychological Scale Preparation]. Yogyakarta: Multi Pressindo

Haris, J. D. (2019). Evaluasi Pembelajaran [Learning Evaluation]. Yogyakarta: Multi Pressindo.

Hanum, N. S. (2013). Keefektifan E-Learning Sebagai Media Pembelajaran (Studi Evaluasi Model Pembelajaran E-learning SMK Telkom Sandhy Putra Purwokerto [The Effectiveness of E-Learning as a Learning Media (Evaluation Study of E-learning Learning Model at SMK Telkom Sandhy Putra Purwokerto]. Jurnal Pendidikan Vokasi, 90-102.

Helmawati. (2019). Pembelajaran dan Penilaian Berbasis HOTS [HOTS-Based Learning and Assessment]. Bandung: Remaja Rosdakarya.

Jayanti, F., \& Arista, N. T. (2018). Persepsi Mahasiswa Terhadap Pelayanan Perpustakaan Universitas Trunojoyo Madura [Student Perception of Trunojoyo University Library Services, Madura]. Kompetensi, 205 - 223.

Lestari, N. D., Rachmawati, D. W., \& Yusmiono, B. A. (2021). Analysis on Portfolio Assessment Leadership Management in Universitas PGRI Palembang. JMKSP (Jurnal Manajemen, Kepemimpinan, dan Supervisi Pendidikan), 6(2), 318-335. 
Listyana, R., \& Hartono, Y. (2015). Persepsi dan Sikap Masyarakat Terhadap Penanggalan Jawa dan Penentuan Waktu Pernikahan (Studi Kasus Desa Jonggrang Kecamatan Barat Kabupaten Magetan Tahun 2013) [Community Perceptions and Attitudes Against Javanese Calendar and Marriage Timing (Case Study in Jonggrang Village, West District, Magetan Regency in 2013]. Jurnal Agastya , 118-138.

Ningsih, M. W., Lestari, N. D., \& Pramika, D. (2021). Development of Accounting Pocket Book as Accounting Learning Media [Development of Accounting Pocket Book as Accounting Learning Media]. Economic Education Analysis Journal, 10(3), 404-415.

Paradikma, G. (2019). Persepsi Mahasiswa KKI IAIN Samarinda Terhadap Implementasi Islam Moderat [Perceptions of KKI IAIN Samarinda Students on the Implementation of Moderate Islam]. Jurnal Penelitian Pendidikan \& Pembelajaran, 11-20.

Sadikin, A., \& Hamidah, A. (2020). Pembelajaran Daring di Tengah Wabah Covid-19 [Online learning in the midst of the Covid-19 Outbreak]. Jurnal Ilmiah Pendidikan Biologi , 214-224.

Saifuddin, M. F. (n.d.). E-Learning Dalam Persepsi Mahasiswa [E-Learning in Student Perception]. 102-109.

Wulandari, \& Nugoroho, E. (2015). E-learning: Implikasinya terhadap pelayanan perpustakaan perguruan tinggi dan peran pustakawan [E-learning: Implications for university library services and the role of librarians]. 